\title{
Globalization, Local Government and Impeachment at Grassroots Level: Nigeria as a Case Study
}

\author{
F. A. Olasupo ${ }^{1}$ \\ ${ }^{1}$ Department of Local Government Studies, Faculty of Administration, Obafemi Awolowo University, \\ Osun-State, Nigeria \\ Correspondence: F. A. Olasupo, Department of Local Government Studies, Faculty of Administration, Obafemi \\ Awolowo University, Osun-State, Nigeria. Tel: 234-80-3406-5576. E-mail:faolasupo@yahoo.com
}

Received: August 28, 2014 Accepted: September 10, 2014 Online Published: October 21, 2014

doi:10.5539/ilr.v3n1p177

URL: http://dx.doi.org/10.5539/ilr.v3n1p177

\begin{abstract}
Of recent, Local Government or what is known in some other countries as Mayor is - and for the first time attracting global attention over impeachment process and its attendant theatrics. Beginning with the Mayor of Toronto who for more than one week entertained the world on Cable Network News (CNN); to the Mayor of Kampala in Uganda; Mayor of Bogota in Colombia; and the countless number of impeached Local Government Chairmen in Nigeria, the stories are the same. Reactions are also the same across the globe; first, for the Mayors themselves, second, for their supporters and, thirdly, for other extraneous factors in the impeachment process. In all of these countries, there are deep involvements of central as well as provincial governments in the impeachments of Mayors for one reason or the other leading to series of theatrics that entertain not just the local, national and the general publics in particular but global audience in general. This paper intends to use Nigeria as a case study of not just how Federal and Provincial governments as well as other godfathers interfere with affairs of Local governments and thus render their (Mayors') autonomies useless against the wish of the Constitutions or Charters, as the case may be, that set them up.
\end{abstract}

Keywords: impeachment, globalization and local government

\section{Introduction}

Political awareness at the local level not just with Local Government Chairmen or Mayors but also the local electorates is ratchet ting up worldwide. With regards to the Chairmen or Mayors, they have been asserting themselves against interference of central or provincial governments through court cases and in most cases the courts have been reinstating them against the wish of central governments. Similarly, local electorates have also been imbibing the culture of protests either in support or against removal of local chief executives.

Other than the electoral process, impeachment is the main means by which elected chief executives, the leaderships of the legislatures and the chief judges of courts could be removed from their respective offices in Nigeria. The responsibility for this, under the presidential system of government, which Nigeria adopted since 1979 , is vested in the various legislatures at all levels of government- federal, state and local. The reality of the exercise of this power by the legislature, however, shows consistent pattern of extraneous forces dictating and shaping the course and patterns of the impeachment processes. Accordingly, whereas threats of impeachment abound at all levels of government, the chief executives are rarely actually impeached, rather, other 'junior' officials become the victims of impeachment. Generally, since the impeachment of Governor Balarabe Musa of Kaduna State in 1980 impeachment of chief executives, especially at provincial level rarely succeed and in this regard the Legislatures at provincial level have remained toothless bull dogs.

On the contrary, legislative houses have, with ease, changed their own leaderships. The same thing can be said of the deputy chief executives who are no more than spare-tyres since they have no constitutional responsibilities beyond the ones assigned to them by their chief executives.

The observations above raised the critical question of whether the legislatures are truly independent of the chief executives and the judiciary as envisaged by the constitution in the performance of their constitutional duties, particularly those relating to impeachment matters. Why is it difficult to impeach the chief executives while the less powerful Deputy Governors, Speakers, Deputy Speakers, Vice/Deputy Chairmen (of local governments) are 
easily removed from offices? What are the behind-the-scenes undercurrents of the impeachment processes in Nigeria? What roles do the chief executives themselves, party leaders and other extra-parliamentary individuals and bodies play in the success or otherwise of impeachment exercises in Nigeria? In short, what are the extra-constitutional factors that shape the patterns and processes of impeachment in Nigeria? These and similar questions are the concern of this paper, which seeks to examining the political undercurrents of the impeachment processes in Nigeria, specifically at the local level.

\subsection{Definition of Terms}

Four terms that need clarification or definition here are the "Chief Executives", "Party Leaders", "Extraneous bodies", "Due Process" and "Impeachment".

Chief Executives at all the levels of government in Nigeria include the President/Vice-President, State Governor/Deputy-Governor and Chairman/Vice-Chairman at the local level (Omololu, 2007).

Party leaders: This refers to leadership of the various political parties, especially the ruling ones at the Local, State and Federal levels. The following officials: Party Chairman, Zonal Chairman, State Chairman, Local Chairman and their Secretaries are very critical in the running of their various political parties at all the levels of government.

Extraneous bodies: This includes individuals and bodies that are not members of parliament but do exercise considerable leverage in moderating debates and other activities of the legislatures at various levels of government, especially the former military Heads of State, Governors and, of course, the Godfathers among other minor ones.

Due Process: This can be defined as the procedure, requirement, parameter or any means guided by rules and regulations to be followed for either taking decision or getting something done in an organization, especially governmental organization. If any of the rules or regulations guiding the procedure, requirement or means of doing something in an organization, especially governmental organization, is perverted for selfish interest of organization official, it amounts to corruption of the due process (Olasupo, 2009: 188).

Impeachment: Osa Iyinbo sees it as "a tool for change in the hands of the legislators". According to him, while ballot is the "only effective weapon available to the people, impeachment is the only effective weapon the legislators possess to remove the Chief Executives. Mike Ikhariale further elaborated that as vote of No Confidence is a weapon of change of the chief executives by the legislators under the Westminster parliamentary system, so is impeachment the weapon of change in the hands of the legislators under presidential system of government. Thus, according to Mike Ikhariale, impeachment "denotes a constitutional process designed to remove a President who has been found guilty of provable acts which, in the thinking of the legislators, amounted to "gross misconduct" (Ikhariale, 2002). According to Edwin Madunagu on the other hand, Whereas sections of the press give the false impression that to impeach means "to remove from office", the real meaning of to impeach is "to accuse a public official before an appropriate tribunal of misconduct in office; to challenge the credibility of; to bring an accusation against; to call into question; to cast an imputation upon; to call into account" (Madunagu, 2003). Finally, to Pini Jason, in a book: Power of Congress, published by the Congressional Quarterly Inc; impeachment is described as "perhaps the most awesome though the least used power of Congress". "The publication went further to describe impeachment as "a political action, couched in legal terminology, directed against a ranking official of the federal government". In the United States, the House of Representative is the prosecutor. The Senate chamber is the courtroom; and the Senate is the judge and jury, said the book. The final penalty is removal from office and disqualification from further office. There is no appeal! (Jason, 2006: 10)

\section{A Brief History of Impeachment}

At the inception, monarchy was the only legitimate form of government ever known to man. However, its inadequacies, among others - autocracy, despotism and nepotism - led mankind to invent other forms of modern government not in one person or institutions but in many persons or institutions. Two of such modern systems are parliamentary and presidential systems of government with each spearheaded by Britain and the United States of America respectively. To prevent these two new modern systems of government from going the ways of monarchy, a number of checks and balances were placed on their paths. One, the people are empowered to vote in and vote out the chief executives and the members of the legislatures periodically (Gordon, 1992: 91). Two, the two new governmental systems were separated into three distinct branches, against the prevailing situation of embodiment of this three in one person under monarchical system of government. While the separated organs of government are expected to cooperate with one another in the process of good governance, they are as well 
expected to act as checks against one another. Thirdly and finally, is the power to remove the chief executive forcefully - impeachment or passing a vote of no confidence, as in the case of parliamentary system of government.

Thus, there are two ways of removing the chief executives - direct and indirect removals. Direct removal has to do with when the electorates vote out the chief executive for lack of performance while the indirect removal of the chief executive is when the legislature whose members were directly elected by the electorates removes the chief executive on behalf of the people. In short, in impeaching the chief executive, the legislature does so, on behalf of the people. In exercising this power, the legislature is not absolutely on its own as it is checked by the judiciary which the constitution vests with the power to appoint the members of the panel of investigators (Azinge, 2002: 166). Additionally, the chief executive or his deputy also has a way of checking the legislature by "defending himself in person and represented by lawyers of his own choice before the investigating committee" obtaining the services of a lawyer at the hearing (Akinsanya, 2005: 177).

Describing the nature of impeachment, Azinge states that "In England, parliament saw impeachment as a powerful weapon of fighting the lords and the executives. It was a means of checking the excesses or despotism from those quarters" (Azinge, 2002: 172). "In America" on the other hand, according to him, "the adoption of the separation of power secured a permanent place for impeachment in the Constitution" (Azinge, 2002: 172). For him therefore, the significance of impeachment "lies in the possibility of instituting proceedings against top public officers who ordinarily are constitutionally immune from prosecution" (Azinge, 2002: 172). Since Nigeria adopted parliamentary system of government in the first republic and is now operating presidential system of government, all the constitutions within these periods made provision for impeachment clauses.

\subsection{Impeachment Procedures}

Nigeria is a country of one Federal authority or government under the presidential system of government adopted in 1979. Prior to this, parliamentary system of government that allowed for two parallel levels of authorities existed. Apart from the Federal government there are also thirty six (36) Provincial governments and seven hundred and seventy four (774) Local Governments. Unlike in other federations, Local Governments in Nigeria are under the control of both the Federal and the Provincial governments. While the Constitution empowers the Provincial governments to create and abolish Local Government, it equally empowers the Federal government to approve them. Thus, unless the two levels of governments work together, no Local Government could be created or abolished and none could be recognized; because all the existing 774 Local governments in Nigeria have their names enshrined in the Constitution. This is to make it difficult to create or abolish any one of them. Indiscriminate creation and abolitions of Local government by Provincial governors between 1979 and 1983 in Nigeria led the military government that came to power in 1983 to 1993 to introduce these stringent conditions. These regularly cause tension among the three levels of government. In this paper, only a State government, Osun State government, will serve as our benchmark.

It is the Nigerian constitution that stipulates how a Governor, Deputy Governor and the Speaker of the House of Assembly could be impeached. The state law enacted by House of Assembly equally has power to enact law by which the Chairman, Deputy Chairman and the leader of the local legislative council could be impeached. With respect to Osun state, virtually all of these elected public officers holders at State and local levels were put into test between 1999 to date. Attempted impeachment was made against Governor Bisi Akande but this was brutally put down by the combined forces of "Governor and Party Leaders" (Olasupo, 2011: 263). However, the most dramatic was that of the Deputy Governor, Chief Iyiola Omisore. Part of the theatrics here was the invitation of thugs, in Osun state, to police the State's House of Assembly since the police appeared to be sympathetic to the Deputy Governor who was believed to have godfathers at the national level. The first time the law makers in Osun State attempted to impeach him, the Deputy Governor was smarter enough to bring in thugs to invade the "House and chased out the legislators". Similar attempts were made on the Speaker of the State House of Assembly as well but these were all deflected (Olasupo, 2011: 263). At the local level, at least two Chairmen, like that of the Deputy Governor, were successful impeached. Impeachment at the local level being our concern here, we shall limit ourselves to it.

\subsection{Local Government Chairmen}

Some Local government chairmen have suffered from dubious impeachment procedures before and after 1999 Constitution. A situation that is similar to what is going on in Toronto, Canada, Kampala Uganda, Bogota in Colombia and Kiev in Ukraine. A handbook on Local Government administration in Nigeria (under military regimes) that preceded 1999 Constitution stated clearly the process and procedure expected to be followed in impeaching a Chairman or Vice-Chairman of a Local government council. According to the book, "A Chairman 
or Vice-Chairman of Local Government who is found guilty of gross misconduct, within the context of the existing laws of the Federation, could be impeached by the Local Government Council" (Federal Republic of Nigeria, 1992:10). It went on to say that "Impeachment is an instrument of last resort designed to enhance public probity and accountability and shall not be employed frivolously, selfishly or as a tool for personal vendetta or political victimization" (Federal Republic of Nigeria, 1992: 10). Finally it concluded that "No Chairman or Vice-Chairman of Local Government shall be deemed to have been impeached until the basic conditions stipulated in the Constitution of the Federal Republic of Nigeria, and other relevant laws, as they relate to the impeachment process, have been fully satisfied" (Federal Republic of Nigeria, 1992: 10).

In Canada, on the other hand, according to John Paul Nelson Gill, "impeachment and removal from office of Canadian mayor is a prerogative that resides in the purview of the public courts and not the applicable electorate". Put simply, Toronto city council cannot just impeach Mayor Ford for whatever legal reason. However, existing law only permits them to remove someone from office if they are incarcerated (www.quora.com/why-does-canada-not-allow-impeachment-of-mayors).

In the United States, the Mayor of Missouri, Mr. Adam Paul, was impeached by a vote of 5 to 1 in April 2013. His impeachment offences, initially included, "among other things, improperly ordering city employees to perform certain tasks, failing to control meetings properly and trying to have the city attorney fired. The Council also alleged that Mr. Paul drank and cursed on the job, but those charges were later dropped from the impeachment resolution". He was however found 'guilty' of another 'impeachable offence' refusal to support Walmart project. Mr. Paul had swept into office in the St. Louis suburb as "a political novice, campaigning against awarding tax incentives to build a Walmart. The Council approved the Walmart project shortly after he took office". It was on that basis he was removed. Mr. Paul claimed the impeachment was retribution for his opposition to building a Walmart. From this point, his lawyer Chet Pleban, picked up the gauntlet, "saying he believed the city charter was unconstitutional in the procedure it outlines for impeachment and the grounds on which it allowed Mr. Paul to be impeached(Eligon, 2013: Online. April 9)".

\subsection{Impeachment Procedure under the Laws of Osun State of Nigeria.}

\section{Chairman or Vice-Chairman}

The laws of Osun State of Nigeria volume 4 states procedure by which the Chairman of a Local Government or Vice-Chairman of a Local Government could be removed.

Ten items that indicate how any of these public officers could be removed are listed thus:

(a) The Chairman or Vice-Chairman may be removed from office in accordance with the provision of this section.

(b) Whenever a notice of any allegation in writing signed by not less than one-half of the members of the council is presented to the Governor stating that the holder of such office is guilty of misconduct in the performance of the functions of his office detailed particulars of which shall be specified, the Governor shall within 7 days of the receipt of the notice cause a copy thereof to be served on the holder of the office and on each member of the Local Government Council and shall also cause any statement made in reply to the allegation by the holder of the office to be served on each member of the Council.

(c) Within 14 days of the presentation of the notice (whether or not any statement was made by the holder of the office in reply to the allegation contained in the notice) the Local Government Council shall resolve by motion without any debate whether or not the allegation shall be investigated.

(d) Within 7 days of the passing of a motion under the foregoing provision of this section, the Chief Judge shall constitute a panel of three judges to investigate the allegation and report to the Governor within 14 days.

(e) The holder of an office whose conduct is being investigated under this section shall have the right to defend himself in person or be represented before the Investigating Panel by a legal practitioner of his own choice.

(f) Where, having considered the report, the Governor decides that the holder of the office is guilty of the allegation, he shall so inform the Local Government Council concerned: Provided that where the Governor decides that the allegation has not been proved, no further proceeding shall be taken in respect of the matter, and the Governor shall inform the Local Government Council concerned accordingly.

(g) On receiving the copy of the decision of the governor that the Chairman is guilty of the allegation, the Local Government Council shall resolve that the Chairman be removed from Office, and give the notice of such a resolution to the Governor for his action: Provided however that the resolution of the Council that the Chairman be so removed shall not be declared as having been passed unless it is supported by the votes of not less than 
two-thirds majority of all the members of the Local Government Council.

(h) On receiving the notice of the resolution of the Council, the Governor shall declare the holder of the office as having been removed from office from the date of passing the resolution and shall thereafter take appropriate step under the Law to swear in a successor.

(i)In this section 'misconduct' means a breach of Oath of Allegiance or Oath of Office or a breach of the provisions of the Constitution or a misconduct of such nature as amounts to bribery or corruption or false declaration of assets and liabilities or conviction for treason or treasonable felony.

(j)Nothing in this section shall preclude the Governor if he is satisfied after due investigation, from suspending any officer to which this section applies for a period not exceeding three(3) months, provided that such a decision is supported by a resolution of the House of Assembly (Osun State, 271-272).

To date, two of some local government chairmen removed from office, in Osun state, through impeachment process, often dubious, were Mr. Nathaniel Arabambi (Ayedaade LG) and Mr. Adebowale Olaoye (Odo-otin LG). In Oyo state the following chairmen among others were removed: Olujide Solomon Ajao (Ibadan North EastLG); Mr. Afolabi (Kajola LG). Lagos state: Engineer (Otunba) Dele Kuti (Ikorodu LG) was suspended from of office. Others from other parts of the country such as Zamfara, Niger, Kano, Rivers, Enugu,Anambra, Kwara and Akwa Ibom states who were impeached are: Solomon Kogi, Aliu Ikara, Aliu Wara, Smaila Gurijian,Mina Cleve Tende, Sunday Anyanwa, Ben Onyin, Chuks Anah, Etheobi Okpala, Emmanuel Ebe, Opaknte Jackreese, Me. Yakubu Jesse, Ikara Bibis, Alhaji Jibrin Sabo Keana (Olasupo, 2006:193). Of course there were those chairmen removed from office by the state Governors by passing procedures. For instance, Kaduna state started it with the removal of $10 \mathrm{LG}$ chairmen. Following Kaduna is Ondo state that has so far removed six LG chairmen : chief Dupe Ogundiminegba (Ose LG); chief Gilbert Adepoju (Ondo East LG); chief Adedayo Adesida (Ondo West LG); chief Siaka Olorunyomi (Odigbo LG); chief Ayeni Olayeye (Okiti pupa LG); and Dr. Francis Ajih (Ese odo).

Where impeachment procedures were adopted in removing Chairmen, most of them were flawed as examples of these abounds. One of such chairmen, impeached by bypassing due process was Chief Dupe Ogundiminegha, the executive chairman of Ose Local Government area of Ondo State under All Nigerian Peoples Party (ANPP). The impeached Chairman was accused of high handedness and malpractice. But the Chairman "explained that his relationship with both councillors and members of the executive council had been cordial since his assumption of office, he noted that prior to the session of the legislative house where he was impeached and he was never invited for discussion". "Neither was I tried by any panel. It was therefore a big surprise only to hear in the news that I have been removed".

Most of the procedural flaws noted with impeachment procedure of Local Government Chairmen stated above are also found in the case of the recent attempted impeachment of the Mayor of Kampala (Pepper, 2013).

Another Chairman of a Local government impeached by suspension was George Osikorobia, the executive Chairman of Ughelli North Local Government. His offences were one, "refusal of Osikorobia to render income and expenditure accounts to the legislative house as prescribed by section 70(5) of the local government law, 1999 of Delta State. Two, "violating section 61(1and 4) of the Local government law". Three, that "in spite of resolutions, invitations, reminders and summon on him by the house, which the Chairman ignored"(Umanah, 2000:35). As a result of all these "the suspension was carried out by six principal officers of the house, against five other members of the 11 member legislature. This is however a simple majority rather than two-third majority that the constitution stipulates.

At the local level could also be found local tyrants wanting to pocket the legislatures and prevent democratic decisions at the cabinet meetings. In Epe local government of Lagos state for instance, the Chairman of the council found guilty of highhandedness against the legislature had to be suspended by the state governor. The legislators accused him of "authoritarian style" in the way he took "over the jobs of supervisory councillors and running the council like his personal household" (Aiyetan, 2001:48). Similar accusation of highhandedness was levelled against Gilbert Nnaji, chairman of Enugu East Local Government in Enugu state. In his own case "he took highhandedness to a new height when he ordered deductions from the salaries of workers in the public health department of the council". In the case of Etsako West Local Government Council, it was the leader of the local legislative house, Miss Abibat Yakubu that was so empowered by the Chairman of the council, Mr Hassan Kadiri and the monarch of the place, Alhaji Aliru Momoh to the point of becoming a tyrant. As the leader of the house, she was expected to initiate impeachment proceeding against the Chairman but refused to do so. For shielding the Chairman from impeachment, the ten other local lawmakers unanimously impeached her (Ogbemudia, 2013:76). 
An interesting question that needed to be asked here is, do impeached public official at the local level have bulwark against the dominion of both federal and State governments? Of course they have but are financially week to exploit it. Judiciary as the last hope of the common man is not free. Huge amount of money (Local government public officials do not have) is required to procure the services of good lawyers, of possible Senior Advocate rank. Even where this is available, there are other powers that the superior levels of government have over and above the local public officials.

For instance, Decree 15 of 1989, (Basic Constitutional and Transitional Provision), empowered the then military president to dissolve any Local Government during the transitional period if he was not satisfied with the management or for any other reasons which he deemed appropriate (Olasupo, 2009:192). Armed with this, Military President Babangida dissolved all the 453 Local Governments that were democratically elected in 1987. Similar central government interference in impeachment process recently took place not only in Uganda but also in Ukraine and Colombia. The Mayor of Kampala, Lukwago is seen as a prominent opposition figure and high profile opponent of Ugandan President, Yoweri Museveni. For his removal on flimsy excuse and devoid of due process, massive protest erupted in Kampala (Voice of America, November 25).

In Ukraine, the president of the country suspended the mayor of Kiev over allegation that he and the deputy security of the President used violence against protesters on 30 November 2013. Currently, there is a massive protest going on in Ukraine not just for the removal of the Mayor but more importantly over the Ukrainians freedom to enter trade relations with Western Europe against the wish of Russian government. However, unconstitutional removal of the Mayor of Kiev presages this (BBC News).

Similar to Uganda's case is the case of Mayor of Bogota, in Colombia, Gustavo Petro, who was sacked from office in a very dubious manner. His removal from office was effected by Colombia's Inspector General, Alejandro Ordonez, who accused the mayor of "mismanagement of the capital's rubbish collection service. Not only that, the Mayor was also banned from holding public office for 15 years. But the Mayor said he had been the victim of a "right-wing coup" by the Inspector General office". The Mayor himself was a former left-wing rebel. In any case, Bogota city was filled with massive protest by the supporters of Petro who say "an unelected prosecutor should not have the power to dismiss an elected Mayor" (BBC News).

The most theatrics of impeachment, suspension or resignation of a Mayor from office was that of Rob Ford, the former Mayor of Toronto, Canada. Series of allegations were levelled against him by his local electorates yet they found it difficult to remove him because there is no constitutional provision for this. He was asked to resign from office, he refused. The council members voted to whittle down his power but still he refused to resign; leading to stalemate in Toronto council. Though he has been divested of all his powers save his removal from office. Yet the electorate of the council are protesting that he should leave office without being able to affect this constitutionally. For more than two weeks the issue was being relayed on CNN. Only recently did he remove himself from re-contesting again due to poor health. This is a good example of constitutionality at work. Ford had constitutional right to claim and he claimed to the end. His strong argument was that neither the Canadian Constitution, Provincial Charter nor Mayoral edict makes provision for impeachment of Mayors. So the stalemate remained until natural solution came on board.

In Nigeria, Some Local Government Chairmen, especially Dr. Sam Orji of Enugu Local Government and Bassey Ekpo Bassey of Calabar Municipal councils that fell victim of Federal government interference in their removal from office and wanted to employ instrumentality of judicial process to right these anomalies, were, again, countered by public office (special provision) Decree of 1984 that prevented the courts form entertaining any suit from anybody arbitrarily removed from public office by the Government (Olasupo, 2009:192)). Though the Constitution made Local government the third tier of government, this is so in theory not in practice as it is the whipping boy of the Federal and State governments. The situation in Kampala, Uganda, is however different. The deposed Mayor went to court to challenge his unconstitutional removal and the High Court of the country presided over by Judge Yasin Nyanzi ordered the reinstatement of the impeached Mayor. As a matter of fact the Judge rebuked the Attorney General, Peter Nyombi for intimidating him (Kenya, 2013). However, it is not clear why the aggrieved Toronto electorates did not want the matter settled in court despite their entire failed attempt to remove the mayor?

\subsection{Local Government Legislative Council}

As are the cases at the state and national legislatures, leaders of local legislative councils also have their own excessive politicking that result in removal of their leaderships. At Nsukka Local Government recently, the leader of Legislative Council, Mr. Dominic Ajibo was improperly removed because the council could not sit to bring this about. When it was time to begin the process of impeaching the leader, the Clerk of the Legislative 
Council, Mr. Joseph Ugwuanyi, ran away with the mace thus preventing members of the council from sitting. However, "the council boss reportedly invited the leader (Ajibo) to his office on Monday and asked him to resign his position in the council (Orji, 2009:8). The accusation made against the leader of the Legislative Council borders on corruption. The councilors in the area want to know how 2 billion naira accruing to the council from the federal allocation was spent. Last but not the least is the case of Akuku local government area where in one fell swoop, the entire leadership of the council was impeached. However, the Chairman of Akuku-Toru local government area of Rivers State, Chief John Briggs, was found to be behind the "masterminding the change in the leadership of the legislative arm of his council"... and for declaring "six councillorship seats vacant". He, himself had to be accordingly suspended from office by the state government.

Only in Lagos state has a local legislative council recently demonstrated its independence of the external forces by removing its leader and reinstating him back as well without the interference of the State government or any godfather. "The leader of Ifako-Ijaye Local Government Legislative House in Lagos State, Hon. Niyi Fadare" was impeached on September 8, 2009 (Okwuofo, 2009:12). Less than a month thereafter, at a plenary session of the council held on $29^{\text {th }}$ September 2009 at the chamber, Iju Areas office, a legislative member, "Hon Babajide Atala, moved the motion that the House revert to the status quo" (Okwuofo, 2009:12). The motion was supported by Hon. Sesi Davids and Fadare, and the pardoned impeached but reinstated legislative leader thanked his colleagues for their maturity.

\section{Observation and Conclusion}

It is observed that at Local government level, not only in Nigeria but in also in Uganda, Colombia, Toronto, Canada, and United States of America, there is need for a device to remove any Chief Executive at local level for grave constitutional abuse of office. This device varies from country to country. For countries practicing parliamentary system of government the device is known as "vote of no confidence", for Presidential system, it is known as "impeachment" but in the case of Canada, particularly with Mayoral government, it is neither of both, which means electorate and the accused chief executive are left to sort thing out by themselves. Rob Ford who recently announced himself out of politics due to poor health is a good example.

Nigeria, Uganda and Bogota need to borrow a leave from both USA and Canada over non-interference of the central and provincial governments in the local issue. Impeachment is one of the tools for removing elected executives and even appointed officials such as the state Chief Judges, for grave offence(s). This is a necessary tool to check abuse of office but following due process of doing so. And here is the problem of the developing countries. Their Constitutions have one of these devices: "Impeachment" or "Vote of no Confidence". What they do not have is adherence to constitutional procedures of bringing this about and this is due, in part, to prolonged military rule in third world countries, especially Nigeria.

Under various military regimes in Nigeria, Sole administrators who were not indigenes of the Local governments were appointed to manage Local government affairs. Their administrative behaviours were not different from those of the military. They were impatient with decision-making not to talk of allowing for due process. Thus, presidentialism and its impeachment device at the local level, is so cumbersome, complex and time wasting to them.

Impeachment device is necessary to check power holders against abuse of it but it should not be a weapon of victimisation or vendetta. Given this background, it will be too much for one to expect our young and inexperienced legislators in this fourth republic to demonstrate sufficient mastery of impeachment procedure, which the new presidential system of government with it cumbersome technicalities, saddle them with.

Lastly, these gales of impeachments in the country, legally or illegally aside, have their positive sides. One, they have put our political institutions - Executive, Legislature and Judiciary into serious test and show that they are, though latent, potentially workable. Two, they have served as positive way of checking the excesses of not only the executive but also the judiciary. Mere announcement of impeachment move not just alerts the public that there is 'fire on the mountain' but also serves as 'wake up' call to the executives to watch their rears.

\section{References}

Aiyetan, D. (2001). Nigeria's New Dictators: Nigeria may have attained democratic rule, but across the nation, at all levels of government, the new men at the helm of affairs still carry on the business of governance in an authoritarian manner reminiscent of the long years of military rule Tell of December 17.

Akinkuotu, A. (2007). Impeachment, Their Impeachment. Tell of March 26. 
Akinsanya, A. A. (2005). The Judiciary and Interpretation of Aspects of the 1979 Nigerian Constitution 1979-1983. In A. A. Akinsanya, \& J. A. Ayoade (Eds.), Readings in Nigerian Government and Politics. Ijebu-Ode, Ogun State: Gratia Associates International.

Azinge, E. (2002). Legislative Adjudication: Uses and Abuses. In C. F. Okolocha (Ed.), Issues and Processes in Legislation: With a forward by Anyim Pious Anyim. Benin City: UNIBEN Press.

BBC. (2013, December 14). Thousands march for sacked Bogota Mayor Gustavo Petro. Online.

BBC. (2013, December 14). Ukraine President Yanukovych suspends mayor of kiev. Online.

Eligon, J. (2013, April 9). Missouri: Mayor Impeached in Feud with City Council. Online.

Fawole, A. (2007, January 21). National Assembly as pillar of democracy. The Westerner.

Federal Republic of Nigeria. (1992). Handbook on Local Government Administration. Abuja: Office of the Vice-President.

Gordon, S. W. (1992). Democracy and the American Revolution. In J. Dunn (Ed.), Democracy the Unfinished Journey 508 BC to 1993. USA: Oxford University Press Inc.

Ikhariale, M. (2002, November). The Impeachment Myth versus the Nigerian Reality. Retrieved from

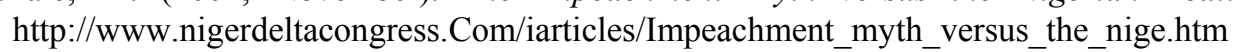

Iyinbo O. (2007, January). Nigeria's Impeachment Saga: Democracy on the Legislature's Butcher Block. Retrieved from http://findarticles.com/p/articles/mi-m5QWD/is_1_5/ ai_n25001269

Jason, P. (2006, October 31). The Weighty Side of Impeachment. Vanguard Newspaper.

Madunagu, E. (2003, February). Impeachment in Nigeria. Retrieved from http://www.nigerdelta congress.com/iarticles/Impeachment_in_nigeria.htm

Majebi, E. (2009, June 26). Wanted: A more secure tenure for Nigerian judges. Retrieved from $\mathrm{http}$ :/www.vanguardngr.com/2009/06/26/wanted-a-more-secure-tenure-for- nigerian-judges-2

Ogbemudia, O. B. (2013, November 24). Otaru saves council boss from impeachment. The Nation Newspaper.

Oji, C. (2009, June 10). Council in crisis over removal of leader. The Nation.

Okwuofo, O. (2009, October 5). Council leader reinstated. The Nation.

Olasupo, F. A. (2005). National Question and Politics at the Local Level. In W. O. Alli (Ed.), Political Reform Conference, Federalism and the National Question in Nigeria. Nigeria: Nigerian Political Science Association.

Olasupo, F. A. (2009). Due Process Corruption in Public Services in Nigeria: Local Government as a Case study. In O. Aborisade, \& I. O. Aransi (Eds.), Public Administration in Nigeria. USA: Catawba Publishing Company.

Olasupo, F. A. (2009). Power Struggle and Impeachment as Means to an End: Osun State as a Case Study, 1999-2003. In M. O. Alabi, \& O. Ajayi (Ed.), Unbroken Legacy of Service: Speaker Bello's Twelve Years under Three Administration in Osun - State. Ilorin: Intellectual Research Institute.

Olayeni, K. (2009, May 17). Ogun Assembly mischievous over my appointment. The Compass.

Omololu, F. (2007). Judicial Review of Impeachment procedure: Implication for Democratic Stability in Nigeria. Paper presented at the annual meeting of the International Society of Political Psychology, Classical Chinese Garden, Portland, Oregon USA, July 04 2007. Retrieved May 24, 2009, from http://www.allacademic.com/meta/p204698_mdex.html

Osun State. (n. d.). The laws of Osun State of Nigeria. Vol. 4 CAPS 68-96 LEG-OSU. England: Antony Rowe Limited, Bumper Farm, Chippenham, Wiltshire. Authorised by the Government of Osun State of Nigeria to print the Laws of Osun State.

Pepper, R. (2013, November 25). Tumwebaze Explains Lukwago Impeachment Process. Red Pepper Newspaper.

Uche, A. (2001, December 24). A Tale of Two Speakers. Source.

Umanah, O. (2000, April 2). LG boss suspended in Delta. Sunday Punch.

Voice of America. (n. d.). News/Africa: Protests Erupts After Kampala Mayor Impeachment. Online. 


\section{Copyrights}

Copyright for this article is retained by the author(s), with first publication rights granted to the journal.

This is an open-access article distributed under the terms and conditions of the Creative Commons Attribution license (http://creativecommons.org/licenses/by/3.0/). 